\title{
Why Rights, Why Now? Reflections on the Rise of Rights in International Development Discourse
}

\section{Andrea Cornwall and Celestine Nyamu-Musembi"}

\section{Introduction}

In the last few years, there has been growing talk among development actors and agencies about a "rights-based approach" to development. ${ }^{1}$ In this article, we seek to unravel some of the tangled threads of contemporary rights talk and to situate competing interpretations of "rights-based" development against a backdrop of the emergence of a discourse on rights among development actors and agencies. We ask why rights have come into favour with international agencies and explore some of the implications of what Eyben (2003a) has called the 'rise of rights' for these agencies. ${ }^{2}$

This article begins with a brief consideration of the normative, pragmatic and ethical justifications for "rights-based approaches" to development. This is followed by reflection on implications that flow from treating rights as a normative framework for development and some of the dilemmas that have been pointed out by proponents of other approaches, such as sustainable livelihoods. We go on to juxtapose current usage of rights language in development with talk of rights in other times, such as in anti-colonial struggles in the 1950s and 1960s and the movement for a New International Economic Order. We conclude with reflections on the challenges and prospects of rights for development.

\section{Situating the turn to rights}

Hausermann (1998) argues that what is distinctive about a human rights approach to development is that it works by setting out a vision of what ought to be, providing a normative framework to orient development cooperation. In doing so, she suggests, it brings an ethical and moral dimension to development assistance, one that by implication has been lacking. ${ }^{3}$ By stipulating an internationally agreed set of norms, backed by international law, it provides a stronger basis for citizens to make claims on their states and for holding states to account for their duties to enhance the access of their citizens to the realisation of their rights. ${ }^{4}$

For some, the grounding of such a "rights-based approach" in human rights legislation makes such an approach distinctively different from others, lending it the promise of re-politicising areas of development work, particularly efforts to enhance participation in development, that have become domesticated as they have been "mainstreamed" by powerful institutions such as the World Bank. Others complain that like other fashions, it has become the latest designer item to be seen to be wearing, and has been used to dress up the same old development in what may amount to the Emperor's New Clothes to occupy, as Uvin (2002) puts it, the high moral ground.

There are rather more pragmatic reasons for the use of rights talk. As we go on to suggest, the current architecture of aid makes new demands for ensuring accountability on the part of recipient states. Ferguson argues that to talk in terms of rights is in itself a 'vehicle for increasing the accountability of government organisations to their citizens and consequently increasing the likelihood that policy measures will be implemented in practice' (Ferguson 1999: 23). Uvin argues, 'the very move from charity to claims brings about a focus on mechanisms of accountability. If claims exist, methods for holding those who violate claims accountable must exist as well. If not, the claims lose meaning' (Uvin 2004: 131). But for actors keen on giving meaning to rights beyond the accepted boundaries of state accountability, the language of a "rights-based 
approach" in the development context also offers the possibilities for an expanded notion of accountability for rights to non-state actors. In its Draft Guidelines for a Human Rights Approach to Poverty Reduction Strategies, the Office of the UN High Commissioner for Human Rights expresses this broader notion of accountability as follows:

Perhaps the most important source of added value in the human rights approach is the emphasis it places on the accountability of policymakers and other actors whose actions have an impact on the rights of people. Rights imply duties, and duties demand accountability.

Under international law, the State is the principal duty-bearer with respect to the human rights of the people living within its jurisdiction. However, the international community at large also has a responsibility to help realize universal human rights. Thus, monitoring and accountability procedures must not only extend to States, but also to global actors - such as the donor community, intergovernmental organizations, international NGOs and TNCs - whose actions bear upon the enjoyment of human rights in any country. (UNOHCHR 2002: paras 23 and 230)

Lastly, a "rights-based approach" can also serve as an opportunity to reflect more broadly on the power dynamics inherent in the practice of international development and on questions of ethics. For Eyben, to talk of rights is to talk about power and about the obligations of those engaged in development assistance (Eyben 2003b; Eyben and Ramanathan 2002). What lies at the heart of such an approach she contends, is an impetus for actors involved in development, to engage reflexively with issues of power. As such, "rights-based approaches" can work both to sharpen the political edges of participation in the wake of the instrumentalism produced by mainstreaming and to make critical linkages between participation, accountability and citizenship (Cornwall 2000; Eyben and Ramanathan 2002; Eyben 2003b; Kabeer 2002; Gaventa 2002).

\section{Who is talking rights? The politics of location}

Rights-talk can function differently from different mouths. It depends who is speaking about rights and where they are speaking ... The same language that may be rhetorical fluff in one place may be words of extreme courage and radical change in another... The use of rights-talk in Washington or Paris might be used piously as new words for the same old liturgy in the cathedrals of international trade and development ... But from another place (a slum or the scene of a rigged election) and spoken from another voice (that of a poor man or a woman land rights lawyer) the same words of rights-talk could function prophetically as a demand for redress to change and challenge power. (Slim 2002, cited in Uvin 2004: 128)

As Hugo Slim so eloquently emphasises, rights talk carries different entailments to other forms of development talk. Unlike other approaches to development, taking a "rights-based approach" puts the spotlight on the politics of the location of development agencies. A commitment to participation, for example, is now voiced across the development spectrum, with the institutions of global governance using the same language as radical social movements. Rights talk brings with it the reciprocal notion of obligation, requiring those who use the language of rights to reflect on their own location.

The implications of the use of rights talk by the development assistance department of a donor nation-state to examine the international human rights obligations of another nation-state, differ considerably from those implied if they were a multilateral lending institution or a global social movement. This is because both donor and recipient states have obligations under international human rights law. The obligations of one nation-state to another (e.g. under a treaty) and to its own citizens are considerably more established and precise than those of multilateral institutions, or international non-governmental organisations (NGOs). The accountability of multilateral institutions to beneficiaries of their programmes is an issue that is still in flux, as the discussion on multilateral institutions below will illustrate. The accountability of international NGOs is often fractured between its dependence on the financial support of rich nation-states and the NGO's beneficiaries in developing countries. Serious discussion about what genuine NGO accountability would look like is only beginning (Archer 2003).

Questions about the geopolitical location of the 
actors promoting and practising a rights-based agenda also echo concerns about the continuity of "new" forms of development intervention that speak of participation, country ownership and rights with (neo)-colonial/imperialist "development business as usual". The Indian MP, S. Jaipal Reddy, for example, draws a distinction between a "rightsbased approach" to public policy at the national or local level and a "rights-based approach" to development cooperation:

A rights-based approach to public policy is most desirable. It needs, however, to come from within. Movement away from political, economic or social oppression can only be sustainable when it springs from within a society and is in harmony with local culture and values. The rights-based approach to development cooperation seeks to bring about empowerment through external pressure and is based on the dogma that all that is required for poverty eradication is "good" leadership, "good governance" and the empowerment of ordinary people. That is patronising to say the least, as it is based on the assumption that good governance is the only missing link between national poverty reduction intentions and actual poverty reduction. The underlying approach seems to be of moral superiority of the donor and also of superiority with regard to insights into what would be in the best interests of the South. (Reddy 2002)

All this makes for an extremely complex configuration of interests, which impinge on how rights talk is articulated, as well as how it comes to inform what is actually done.

\section{Historical dimensions}

Locating the turn to rights historically further complicates the tale. What is now termed the "rights-based approach" to development has a relatively recent history in the discourse of international development agencies, emerging in the post-Cold War period in the early 1990s, and gathering momentum in the build-up to the Copenhagen Summit on Social Development in 1995. Yet many of the principles which are articulated as part of this approach are not new. They have been part of struggles for self-definition and for social justice long before the discourse of rights "went global" in the post-World War II period. It is ironic to reflect on the framing of current rights discourses given these antecedents. Many of the tensions and possibilities that flow from the articulation of a "rights-based approach" to development need to be understood as emergent from longer-standing relations between the states, powers and institutions that are involved in current rights discourse.

\subsection{Precedents: "rights" in anti-colonialism struggles}

Talk of rights in development may be new among international agencies. But struggles for the realisation of social, economic and cultural, as well as civil and political, rights have long been a feature of the political landscape in many developing countries (see Miller et al., page 52 this issue). Rights talk was, and remains, a defining feature of resistance and liberation movements in developing countries. Nationalist and anti-colonial movements framed their demands for self-rule in terms of the everyday constraints that colonial administrations imposed not just on their liberty, but on their livelihoods (Mamdani 1996; Kabeer 2002). In these settings, the right to citizenship was not regarded in the classic liberal sense as something bestowed by a benevolent nation-state, together with a bundle of entitlements to which individuals could lay claim. It was seen as something that needed to be fought for and won, on the basis of prejudice against and the exclusion of the majority of the population from participation in the decisions that affect their lives and on the basis of the lack of obligation on the part of the state to guarantee certain basic rights. Manji argues:

The struggle for independence in Africa was thus informed, at the base, by the experience of struggles against oppression and brutal exploitation experienced in everyday life. These struggles constituted the emergence of a tradition of struggles for rights which was organic to and informed by the specific histories and experiences of those involved ... The concept of rights was ... forged in the fires of antiimperialist struggles. It was informed by the need to overthrow all forms (not just colonial) of oppression and exploitation, not by constructs which had either been embodied in the UDHR or imported into Africa by those nationalist 
leaders who had spent periods in exile or study in the imperial homeland. (Manji 1998: 14)

It was in the act of struggling that rights were articulated and came to form the basis for action for social justice (Mamdani 1996; Manji 1998; Nyamu-Musembi 2002). Rights, in the broader sense of awareness of injustice, in contexts such as these was something that sprang from popular opposition to colonial rule, whether in incidents like the Aba Women's War in Nigeria or the rebellions of Kikuyu women in colonial Kenya, or the mobilisation of anti-colonial forces in Zimbabwe's Chimurenga wars and the non-violent direct actions led by Gandhi in India. It was with the advent of "development", Manji charges, that the social energy created through popular organisation began to be dissipate as the state took over, codifying rights in 'laws and constitutions whose relevance or application was determined by the self-proclaimed, and increasingly unaccountable, guardians of the State' (Manji 1998: 16). The shift from rights to development, Manji argues, hastened the depoliticisation of "poverty". With it came the transmutation of the structures that had emerged to organise around basic rights into "development" institutions.

Some would charge that today's rights-based development ignores this history. It certainly resonates remarkably little with its politicised history, given the locus of those who are its principal promoters. What does seem evident is that scant attention appears to be paid to the fact that the very agencies which are trying to promote it have their own situated relationships with the countries in which they are engaging; the case of Britain and its ex-colonies being the most obvious example. Yet there are other dimensions of this history that are worth remembering. The colonial project was uneven and contradictory: it was not a seamless process of extraction and oppression. Spaces were opened through its contradictions for certain social groups, for instance, women, to gain access to new opportunities and realise new rights that traditional society did not recognise. ${ }^{5}$ This gave rise to tangible new opportunities for certain excluded groups. The paradox of the ways instrumentalist intervention was actively transformed by people into something that they could make use of in securing freedoms has considerable contemporary resonance, as we suggest later in this article.

\subsection{The right to development: demanding a new international economic order}

From the colonial era to the period after World War II in which "development" began to be articulated as a project with the dimension of international cooperation, "development" and "human rights" were seen as separate domains. "Development" was the terrain of economists, for the most part; "human rights", the territory of lawyers and activists (UNDP 2000). It was, Mary Robinson argues, the entry of newly independent southern nations into the United Nations in the 1960s and 1970s that spurred the beginnings of attempts to bridge the two domains (Robinson 2001). The 1966 International Covenant on Economic, Social and Cultural Rights provided an important starting point for a host of Third Worldled initiatives one of whose outcomes was the Declaration on the Right to Development in 1986.

The 1986 UN Declaration on the Right to Development marked one key milestone in a decade and a half of struggles by radical Third World states within the UN to pass a package of reforms that would result in a New International Economic Order (NIEO) that was fair to poor countries. The declaration is non-binding, and some view it as a watered down version of the radical redistributive measures sought by the NIEO movement. Nonetheless it does reflect some of the radical politics of that era. For instance, rather than confine itself to a conventional understanding of rights as being about state-citizen relations, it places an emphasis on the global dimension. Pointing to inequalities between North and South, it stresses the collective obligation of all states to create a just and equitable international environment for the realisation of the right to development. It emphasises a collective duty of all states to eliminate barriers such as unfair trade rules and the debt burden, effectively pointing an accusing finger at the industrial countries. For this reason it has been opposed by Western states.

The voting pattern on the resolution adopting the declaration shows this North-South split. ${ }^{6}$ Although eight industrial states voted in favour of adopting the declaration, this number dropped drastically when a subsequent resolution tried to lay out a detailed plan of action to put the Right to Development into practice (Res 41/133 of 4 Dec 1986). ${ }^{7}$ This second resolution called for international cooperation aimed at stable and 
sustained economic growth and increased concessional assistance to developing countries. It called on states to build world food security, resolve the debt burden, eliminate trade barriers, promote monetary stability and enhance scientific and technical cooperation (Brownlie 1989: 12). The industrial countries rejected this because they saw it as the imposition of one-sided obligations and an invasion into what should be, according to them, the discretionary/voluntary field of development assistance, where spelling out precise obligations is anathema.

Within the arena of international human rights practice, there continued to be some resistance over the course of the later 1980s and 1990s to the types of rights that were seen as "development concerns", for example shelter, water and food. Resistance to economic and social rights by the West (especially the USA) has roots in the Cold War and the situation has changed since it ended. The principle of the indivisible, interdependent and non-hierarchical nature of rights has become the mantra since the 1993 World Conference on Human Rights held in Vienna. However, social and economic rights still encounter a degree of scepticism (mostly US-led) as to their status as rights. Mainstream Westernbased human rights NGOs only began to work on these since the mid-1990s. Indeed, the human rights movement has tended to remain aloof to issues of economic and social justice. Mainstream human rights groups such as Amnesty International did not get into the language of "rights-based approach" to development' until 2001/2 (Amnesty International 2002).

Contemporary talk about "rights-based approaches" within international development circles displays little awareness of the earlier struggles around the Right to Development. The absence of the Right to Development from the rights vocabulary of international development actors is explained partly by a deliberate effort to steer clear of the controversies raised by its reference to global inequalities. The UK Department for International Development (DFID) for instance, makes no reference to the Right to Development in any of its two White Papers and only a passing reference in the Target Strategy Paper on rights (DFID 1997; DFID 2000b; DFID 2001). The UK Foreign and Commonwealth Office specifically advised proponents of a "rights-based approach" within DFID to exclude any reference to the declaration.
DFID makes it quite clear that it does not ground its approach to development assistance in the UN Declaration on the Right to Development and that its assistance is based on a moral, not legal, obligation to alleviate poverty (Piron 2003). The other partial explanation is simply the staff's lack of familiarity with these earlier struggles. ${ }^{8}$

\subsection{Why rights, why now?}

Why then, in view of this history of hostility to the language of rights in the development sphere, have international development agencies shown less hostility (indeed in some cases, shown enthusiasm) to the mid-1990s discourse on "rights-based approach" to development? A confluence of factors has contributed to growing interest among development actors in "rights-based approaches" to development, which are explored below.

\section{The end of the Cold War}

The end of the Cold War made possible a more comprehensive view of rights as encompassing all rights: civil, political, economic, social and cultural. From this point, it is not a long jump to framing "development" concerns such as food security and population as issues of rights. There is less contestation over their status as rights claims, unlike the sterile and polarised debates that characterised the Cold War era. ${ }^{9}$

\section{NGO activism}

A "development caucus" made up largely of "development" and "humanitarian relief" NGOs, as well as disparate small groups or movements based in the South spearheaded a campaign for a "rightsbased approach" at the World Social Development Summit at Copenhagen in 1995. The campaign was not led by the mainstream international human rights movement, as one would expect. But changes in the attitudes of mainstream human rights groups did influence this campaign. While the prominent core of the movement (namely large Western-based NGOs) had remained aloof to issues of economic and social justice, this situation began to change around the time of the Vienna Conference on Human Rights in 1993. The Vienna conference is significant in that it was the first post-Cold War international conference on human rights and therefore it emphasised the integrated nature of rights, thus raising the profile of economic and social rights. Thus, by the time of the Copenhagen summit, there 
were a few examples of collaboration between mainstream human rights NGOs and developmentoriented NGOs (Nelson and Dorsey 2003).

\section{Shifts in aid delivery}

In general, the disbursement of development assistance has begun to shift in recent years from sector-specific or project-based intervention to direct budget support to governments. Much aid still takes the shape of programme or project support, but budget support delivered through coordination between donors is becoming the new modality for aid. Budget support offers donor governments opportunities to influence the shape of recipient government policies, and some opportunities to affect service delivery. But the challenge remains as to how donor governments can ensure that this money is actually spent accountably once it is released into the recipient country's treasury. The response has been to support a two-way process: reform and strengthening of public institutions on the one hand and bolstering the capacity of civil society to hold the public sector to account on the other (Jenkins and Goetz 1999; Goetz and Gaventa 2001). Within this context, the turn to rights might be seen as a means through which the kinds of openly intrusive conditionalities that no longer befit today's rhetoric of partnership and policy dialogue can be brought in through another route.

\section{Rights as a way of reframing participation}

While broad-based participation is now seen as an important means through which rights can be claimed and gained, the effective separation between participation as a means through which projects and programmes were implemented, and participation as a political process involving advocacy and mobilisation, dominated approaches to participation in the 1990s (Gaventa and Valderrama 1999). For some of those working with participation, the turn to rights at the end of that decade came as a way of re-politicising an approach to development that had turned instrumentalist as it was popularised in the mainstream. Rights talk provides a new frame within which to signal a move towards a more genuinely inclusive and democratic process of popular involvement in decision making over the resources and institutions that affect people's lives. The focus of rights-based versions of participation is about shifting the frame from assessing the needs of beneficiaries or the choices of customers or clients, to foster citizens to recognise and claim their rights and obligation-holders to honour their responsibilities (Eyben and Ramanathan 2002; Eyben 2003b; Cornwall 2000).

\section{Distancing the discourse of "rights-based} approaches" from the right to development

Finally, what has made the language of "rights-based approaches" at least tolerable to the institutions that have been careful to keep the Right to Development at arm's length? We speculate that it is because the mid-1990s dialect of the rights language is shorn of any reference to the global inequality that is the central focus of the 1986 declaration. In the mid1990s dialect, there is no conception of human rights duties beyond that of one's "own-state". In fact, even though rights-based language is being employed in the context of "international cooperation" and in "aid", it is quite clear that the funder countries, while insisting that they now see the people in the recipient countries as rights-bearers, do not see themselves as bearing any defined duties that contribute to the concrete realisation of these rights. Beyond the acknowledgement that the primary duty flows from the recipient state to its citizens, it is not clear where the funder countries position themselves in the "rights-duties" equation.

When a "rights-based approach" is deployed in the context of bilateral and multilateral assistance programmes, where do the obligations lie? We would assume primarily with the recipient state, to ensure that the aid is used in a manner that respects and fulfils its citizens' rights. What then is the position of the funding government: does it also invite upon itself obligations to monitor the recipient government's disbursement and use of its funds to ensure that it is consistent with human rights principles? Does it take responsibility for any negative human rights impact flowing from projects it has funded? None of these implications are explained clearly in any agency's policies. Perhaps it is the lack of clarity on corresponding duties that makes the contemporary language of rights in development less threatening to the governments of rich countries than the Right to Development?

\section{Changing power relations?}

Ultimately, however it is operationalised, a "rightsbased approach" would mean little if it has no potential to achieve a positive transformation of power relations among the various development 
actors. Thus, however any agency articulates its vision for a "rights-based approach", it must be interrogated for the extent to which it enables those whose lives are affected the most to articulate their priorities and claim genuine accountability from development agencies, and also, the extent to which the agencies become critically self-aware and address inherent power inequalities in their interaction with those people (see Hughes et al., this issue).

In the context of bilateral development assistance, it seems difficult to envision this level of transformation because of the manner in which accountability channels in aid relationships are currently structured. A bilateral development agency's primary accountability is to citizens/ taxpayers in its own country, through the treasury. Accountability to the recipient state's government is of a loose diplomatic nature, rather than a legal one, with clearly defined rights and obligations. The Memoranda of Understanding entered into has no binding legal force. Direct accountability to the communities which are the ultimate recipients is non-existent. ${ }^{10}$ This is as much, if not especially, the case for NGOs, most of which lack any defined accountability and are even less amenable to being held to account than multilateral or bilateral development actors. The only formal accountability communities can expect is from their own government. Likewise, recipient governments have only a loose accountability to donor governments; accountability based on the power differential rather than on legal obligations.

Without the possibility of direct accountability in the international development assistance structure, is there any substance to the claim in current donor literature that aid recipients have now been transformed from 'passive beneficiaries' to 'rights-holders'? What rights exactly do they hold? A question for reflection therefore is, in view of the absence of the key ingredient that distinguishes a "rights-based approach" from a practice of development that is dictated by discretion and pragmatism, can the policies of bilateral agencies be described as rights-based? It seems fair to suggest that international development agencies, to varying degrees, use the language of "rights-based approach" to development largely to invoke the discursive power of the concept of rights, without intending to bear the weight of the entirety of consequences that flow from it.

At the same time, as Peter Uvin argues, discursive shifts can 'slowly reshape the margins of acceptable action, create opportunities for redefining reputations and naming and shaming, change incentive structures and the way interests and preferences are defined, and influence expectations' (Uvin 2002: 2). Drawing attention to the shortcomings of the kind of rhetorical flirtation with rights that is evident in the international development community is critical at this juncture if rights talk is to mean anything more than the latest flurry of cosmetic rhetoric with which to sell the same old development. In this case, the devil lies in the detail and in the extent to which a "rightsbased approach" can work to bridge the disjunctures and dissonances that characterise the relationship between nice words and everyday development practice.

The challenge is as much that of pragmatics as of principle, and is one of aligning human rights principles with the everyday procedures and practices of development agencies, whether methodological, programmatic or evaluative, in ways that can embed them in the work that international development agencies do. Given the dubious successes with previous mainstreaming efforts, there may be scepticism about how much international agencies will be able to use this approach to transform the way in which the development industry works. In the current international climate however, "rights-based" hopes are as good as it gets and may well, at last, provide the scope for the kind of changes that are so desperately needed. 


\section{Notes}

* We would like to thank our funders, the Swedish International Development Agency (Sida), the UK Department for International Development (DFID) and the Swiss Agency for Development Cooperation (SDC). We would also like to thank the people from international agencies who gave their time to share their views with us. All errors of interpretation remain ours. This article draws substantively on a longer version entitled 'Putting the "rights-based approach" into perspective', published in Third World Quarterly, Vol 25 No 8, December 2004.

1. These trends are captured in 'The rise of rights' (Eyben 2004a); and evidenced in a range of recent documents from international NGOs and donor agencies, from CARE's 'Defining characteristics of a "rights-based approach": promoting rights and responsibilities' (CARE 2002), to DFID's Target Strategy Paper, 'Human rights for poor people' (DFID 2000a).

2. In doing so, we draw on a longer and more detailed exploration of different international development agencies' positions on "rights-based approaches" (NyamuMusembi and Cornwall 2004).

3. Others would argue that such a vision is so infused with the values of the Enlightenment that its cultural and historical specificity undermines any claims to universality (see Kabeer 2002).

4. As the Committee on Economic, Social and Cultural Rights made clear, such obligation extends to the creation of enabling conditions rather than direct provisioning.

5. One example of contradictions within the colonial project that opened up spaces for some social groups is in the area of marital relations. Chanock (1985) discusses the example of a colonial officer and a Chewa paramount chief in North Eastern Zambia in the 1920s, who took it upon themselves to grant divorces to rural women who had been abandoned by their husbands. The husbands had migrated into mining centres and towns and had entered into relationships with other women and did not remit money to their wives. Yet, the area's Native Authorities and the Catholic Missionaries would not allow them to divorce their husbands. The unilateral actions of the colonial officer and the Chewa paramount chief freed them to move on and explore new economic opportunities for themselves.

6. There were 146 votes in favour. Industrial countries which voted in favour of the declaration included Australia, Belgium, Canada, France, Italy, Netherlands, New Zealand and Norway. The single vote against the declaration came from the USA. Eight abstained, including Japan, Germany and the UK (Brownlie 1989).

7. On this subsequent resolution, 11 states voted against (USA, Belgium, Canada, France, Germany, Italy, Japan, Luxembourg, Netherlands, Portugal and the UK). The total number of votes in favour fell to 133. Australia, which had voted in favour of the first resolution, abstained this time around (Brownlie 1989).

8. A workshop on 'Rights and Power' held at IDS in November 2003 included an exercise to draw out the key historical events that have influenced the emergence of "rights-based approaches" in development. When the Declaration on the Right to Development was mentioned by one of the authors, no more than four of the 26 participants drawn from donor agencies had ever heard of it.

9. See Uvin (2004) for a fuller discussion of the emergence of human rights discourses within the development arena.

10. Some development agency practitioners have suggested possible innovative ways to fill this gap. See, for example, Eyben (2004b). 


\section{References}

Amnesty International, 2002, 'The rights based approach to development: indivisibility and interdependence of ALL human rights', statement of Colm O'Cuanachain, Chairperson, International Executive Committee to World Social Forum, Porto Alegre

Archer, R., 2003, Deserving Trust: Issues of Accountability for Human Rights NGOs, Geneva: International Council on Human Rights Policy

Brownlie, I., 1989, 'The human right to development', Human Rights Unit Occasional Paper, London: Commonwealth Secretariat, November

CARE, 2002, 'Defining characteristics of a "rights-based approach": promoting rights and responsibilities', Newsletter, London: CARE, February

Chanock, M., 1985, Law, Custom and Social Order: The Colonial Experience in Malawi and Zambia, Cambridge: Cambridge University Press

Cornwall, A., 2000, 'Making a difference? Gender and participatory development', IDS Discussion Paper 378, Brighton: Institute of Development Studies

DFID, 2001, Making Government Work for Poor People: Strategies for Meeting the International Development Targets, London: Department for International Development

DFID, 2000a, 'Human rights for poor people', Target Strategy Paper, London: Department for International Development

DFID, 2000b, 'Eliminating world poverty: making globalization work for the poor', White Paper on International Development, London: Department for International Development

DFID, 1997, 'Eliminating world poverty: a challenge for the 21st century', White Paper on International Development, London: Department for International Development

Eyben, R., 2004a, 'The rise of rights', Policy Briefing 17, Brighton: Institute of Development Studies

Eyben, R., 2004b, 'Donors, rights-based approaches and implications for global citizenship: A case study from Peru', in N. Kabeer (ed.), Meanings and Expressions of Citizenship, London: Zed Books

Eyben, R., 2003a, 'International development organizations and rights based approaches', presentation to 'Rights and Power' workshop, Institute of Development Studies, Brighton, November
Eyben, R., 2003b, 'The rise of rights: rights-based approaches to international development', IDS Policy Briefing 17, Brighton: Institute of Development Studies

Eyben, R. and Ramanathan, U., 2002, 'Rights-based approaches to inclusive development: perspectives on the implications for DFID India', mimeo, London: Department for International Development

Ferguson, C., 1999, Global Social Policy Principles: Human Rights and Social Justice, London: Department for International Development

Gaventa, J., 2002, 'Introduction: exploring citizenship, participation and accountability', IDS Bulletin, Vol 33 No 2: 1-11

Gaventa, J. and Valderrama, C., 1999, 'Participation, citizenship and local governance', background note prepared for workshop on 'Strengthening Participation in Local Governance', Institute of Development Studies, Brighton, 21-24 June

Goetz, A.-M. and Gaventa, J., 2001, 'Bringing citizen voice and client focus into service delivery', IDS Working Paper 138, Brighton: Institute of Development Studies

Hausermann, J., 1998, A Human Rights Approach to Development, a discussion paper commissioned by the Department for International Development of the UK Government in preparation of the Government White Paper on International Development, London: Rights and Humanity

Jenkins, R. and Goetz, A-M., 1999, 'Accounts and accountability: theoretical implications of the Right-to-Information Movement in India', prepared for workshop on 'Strengthening Participation in Local Governance', Institute of Development Studies, Brighton, 21-24 June

Kabeer, N., 2002, 'Citizenship and the boundaries of the acknowledged community: identity, affiliation and exclusion', IDS Working Paper 171, Brighton: Institute of Development Studies

Mamdani, M., 1996, Citizen and Subject: Contemporary Africa and the Legacy of Late Colonialism, Princeton: Princeton University Press Manji, F., 1998, 'The Depoliticisation of Poverty', in D. Eade (ed.), Development and Rights, Oxford: Oxfam

Nelson, P.J. and Dorsey, E., 2003, 'At the nexus of human rights and development: new methods and strategies of global NGOs', World Development, Vol 31: 2013-26 
Nyamu-Musembi, C., 2002, 'Toward an actororiented perspective on human rights', IDS Working Paper 169, Brighton: Institute of Development Studies

Nyamu-Musembi, C. and Cornwall, A., 2004, 'What is the rights-based approach all about?', IDS Working Paper 234, Brighton: Institute of Development Studies

Piron, L.-H., 2003, The Right to Development: A Review of the Current State of the Debate for the Department for International Development, London: Overseas Development Institute, www.odi.org.uk/pppg/publications/papers_repo rts/dfid/issues/rights01/index.html (accessed September 2004)

Reddy, J., 2002, 'Statement by Mr. Jaipal Reddy, Member of Parliament on Agenda Item 89: Implementation of the First United Nations Decade for the Eradication of Poverty at the Second Committee of 57th Session of the UN General Assembly on October 30, 2002', New York: United Nations, http://secint04.un.org/ india/ind661.pdf (accessed September 2004)

Robinson, M., 2001, 'Bridging the gap between human rights and development: from normative principles to operational relevance', World Bank, Presidential Fellows Lecture, 3 December, Washington, D.C.: World Bank, www.worldbank.org/wbi/B-SPAN/ sub_mary_robinson.htm (accessed September 2004)

Slim, H., 2002, 'A response to Peter Uvin - making moral low ground: rights as the struggle for justice and the abolition of development', PRAXIS The Fletcher Journal of Development Studies, Vol XVII

UNDP, 2000, Human Development Report: Human Rights and Human Development, New York: United Nations Development Programme

UNOHCHR, 2002, Draft Guidelines: A Human Rights Approach to Poverty Reduction Strategies, Geneva: Office of the United Nations High Commissioner for Human Rights, www.unhchr.ch/development/ povertyfinal.html (accessed September 2004)

Uvin, P., 2004, Human Rights and Development, Bloomfield: Kumarian Press

Uvin, P., 2002, 'On high moral ground: The incorporation of human rights by the development enterprise', PRAXIS The Fletcher Journal of Development Studies, Vol XVII 